\title{
Bons ventos na pesquisa em educação e história de Ciências da Terra
}

Profissões dedicadas ao estudo da Terra são essenciais em países populosos, para garantir suprimento de água, energia, matérias-primas, prevenção de desastres naturais, conservação de geossítios e difusão do conhecimento geocientífico na educação formal. No Brasil, entretanto, o número de profissionais formados a cada ano em cursos de graduação é insuficiente para suprir as necessidades. Para alterar o quadro, a criação de novos cursos superiores é solução transitória que pode se revelar inócua, se não houver recursos humanos e materiais adequados para suportá-los e sem a decidida avaliação do Estado para garantir que a força de trabalho resultante detenha a competência esperada.

Terræ Didatica busca auxiliar o enfrentamento desse imenso desafio: 43 artigos foram publicados em 2014, revigorando a difusão e o debate de temas educacionais em Ciências da Terra. O êxito da iniciativa, que equivale em número de páginas a tudo que se publicou nos seis primeiros anos, se deve à decisão de publicar os anais de Interfaces Geociências e Ensino: 40 anos de experiências (1973-2013) [Unicamp, 23 e 24 de agosto de 2013], evento que registra a origem, a trajetória e os desdobramentos de ações de um grupo de ensino-pesquisa e do bem-sucedido Programa de Pós-Graduação em Ensino e História de Ciências da Terra da Unicamp.

Já enfatizamos antes que boas ideias ganham vida própria e ultrapassam quem as criou.

Os números regulares de Terræ Didatica reunem artigos que passaram por severa avaliação editorial. O índice de rejeição final pelo corpo editorial tem sido baixo pois, em lugar da devolução categórica, adotam-se mecanismos de interação com autores para melhorar forma e conteúdo. Os manuscritos são espontaneamente submetidos pela comunidade; o rigor da avaliação dá mais qualidade ao que finalmente se publica. Além desses fatores, o número 10(3) constitui uma edição temática. A ideia é atraente e merece ser replicada no futuro.

Terræ Didatica manterá periodicidade quadrimestral em 2015, mas existe clara intenção de torná-la trimestral.

A primeira edição de 2015 contém textos básicos e experiências educativas com docentes e alunos: "abordagem teórico-metodológica sobre geodiversidade e análise da paisagem"; "capacitação em solos para professores de educação básica", "paleontologia no ensino fundamental de três regiões brasileiras"; "alfabetização científica no ensino fundamental em Rondônia". A curiosíssima origem do nome do mineral porpezita é analisada nesta edição, que é finalizada com uma síntese de conhecimentos sobre o tema "fitólitos no Brasil".

Continuamos buscando apoio e patrocínio de empresas, fundações e órgãos de governo. Cogita-se abrir a possibilidade de que pessoas físicas contribuam financeiramente ou façam doações para a revista. A todos que apoiam Terræ Didatica, dedicamos nosso agradecimento.

Os editores

Campinas, abril de 2015. 